
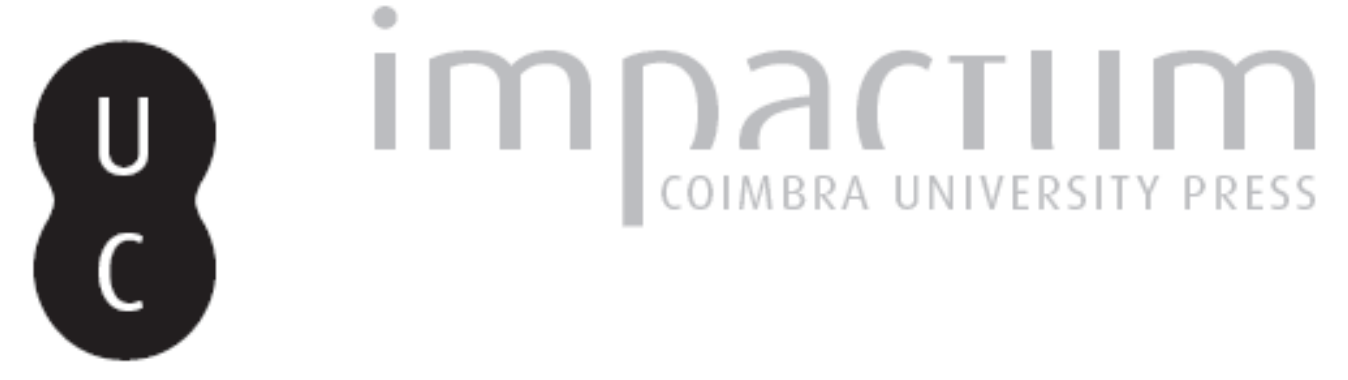

\title{
Colonial media and post independence experience in north Africa
}

Autor(es): Zaghlimi, Laeed

Publicado por: Imprensa da Universidade de Coimbra

URL persistente:

URl:http://hdl.handle.net/10316.2/39636

DOI:

DOI:http://dx.doi.org/10.14195/2183-5462_29_10

Accessed : $\quad$ 26-Apr-2023 13:17:16

A navegação consulta e descarregamento dos títulos inseridos nas Bibliotecas Digitais UC Digitalis, UC Pombalina e UC Impactum, pressupõem a aceitação plena e sem reservas dos Termos e Condições de Uso destas Bibliotecas Digitais, disponíveis em https://digitalis.uc.pt/pt-pt/termos.

Conforme exposto nos referidos Termos e Condições de Uso, o descarregamento de títulos de acesso restrito requer uma licença válida de autorização devendo o utilizador aceder ao(s) documento(s) a partir de um endereço de IP da instituição detentora da supramencionada licença.

Ao utilizador é apenas permitido o descarregamento para uso pessoal, pelo que o emprego do(s) título(s) descarregado(s) para outro fim, designadamente comercial, carece de autorização do respetivo autor ou editor da obra.

Na medida em que todas as obras da UC Digitalis se encontram protegidas pelo Código do Direito de Autor e Direitos Conexos e demais legislação aplicável, toda a cópia, parcial ou total, deste documento, nos casos em que é legalmente admitida, deverá conter ou fazer-se acompanhar por este aviso.

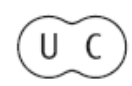




\section{Media Jornalismo}

\section{MÉDIA E COLONIALISMO(S)}




\title{
COLONIAL MEDIA AND POST INDEPENDENCE EXPERIENCE IN NORTH AFRICA
}

\author{
LAEED ZAGHLAMI \\ ALGIERS UNIVERSITY 3, FACULTY OF INFORMATION AND COMMUNICATION, \\ MASS COMMUNICATION DEPARTMENT \\ EL BIAR, 16606, ALGERIA \\ LZAGHLAMI@GMAIL.COM
}

Abstract

European colonialism had not only occupied many african countries, exploited their natural resources and deprived their inhabitants of basic rights, but also sought to establish its new political, social, economic and cultural system. However, in order to impose its new rules and values, it had used military forces as well as political and media means to convince and influence people minds and hearts. The press was one of the main arguments of seduction and dissimination of the colonial culture and information.

This paper which focuses in its first part on French occupation of North Africa, describes how French colonial authority used and abused the media to perpetuate its presence and set up new forms of values and ideas aimed at destroying local culture and traditions. The second part describes how local populations had reacted to the coIonial presence by adopting new forms of opposition and resistance. Again, the 'indigenous press' was a determining factor in promoting ideas of militantism, independence and sovereignty. The third part highlights the main phases of the media evolution and experience during the post independence period.

\section{KEYWORDS:}

Colonialism, occupation, militancy, independence, new order of information, state monopoly diversity and pluralism.

\section{INTRODUCTION}

French colonial forces were present in North African countries under the protectorate status, however, in the case of Algeria, it was a tough and cruel occupation. In fact, France invaded the country in 1830 and remained until 1962 - agreeing to independence after seven years of fighting and a deadly struggle against the colonisers. Although, North Africa region is often considered as a political and cultural homogenous bloc as it had been influenced by French occupation. However, in reality there are significant differences between countries of Arab Maghreb in terms of political system, economic model, culture and media policies. Thus, Morocco was erected as a kingdom with a liberal economic policy, Tunisia adopted a republican regime led by president Habib Bourguiba from 1956 until his removal in 1987. Its economy was liberal orientation in comparison to Algeria, which gained its independence in 1962, but adopted a unique party system and set up socialist regime until 1988 which ignited political changes to democracy and pluralism. 


\section{First Colonial Papers}

The very first paper in the region was a Spanish one called African Liberal, published in Morocco in 1820, followed by a French newspaper published in Algeria in 1830, called I'Estafette de Sidi Ferrudj. The Al Moubashir paper was introduced in North Africa in 1847(1). The press in the region was therefore first brought by the colonisers in the early part of the 19th century. Thus, during early years of occupation, the French colonisers extended their rule by publishing numerous papers in the region that were owned and controlled by them. Only a few papers belonged to the indigenous people, though they were also used to convince more indigenous people to explicitly admit the usefulness of the French presence. This press was dedicated to attracting sympathy and support from the local population, and acceptance of the French as the new rightful occupiers. Further, the press served the colonial presence by praising the French "positive contribution" to solving the local population's problems.

\section{The Birth of Colonial Press}

Colonial press was considered as an instrument to introduce civilisation, culture, education and development to the local populations. It tried to forcefully perpetuate the French occupation. However, there was a series of acts of violence, uprisings, upheavals which culminated with an armed struggle in November 1954 in Algeria. It is necessary to recall that in 1881, the colonisers adopted a press law that considered Arabic language of local populations as a foreign language.

Printing in Arabic and importing Arabic papers were perceived as serious violations of the law and therefore were not allowed. But in order to contain and embrace more indigenous people into the French citizenship, the press law enabled holders of rights to have their own publications. However, local populations strongly reacted by rejecting the new rules (2). The 1930s marked the rise of the Muslim and nationalist press and started to advocate more reforms, democratic rights and independence. But, these demands were met by French occupation with fierce opposition, repression and severe measures, banning journalists and papers closures (3). As a consequence, many journalists changed their working conditions, worked in secrecy and in clandestinity until the 1950s, when a strong and deeply rooted movement of liberation began to fight for the advance of the cause of independence and the recovery of the national sovereignty.

\section{Militant Journalists and nationalistic media}

The nationalist press in North Africa emerged in the $20^{\text {th }}$ century as an alternative to defy and challenge the repressive rule of colonialism. In Morocco for instance, in 1944, two papers - Al Alam (The World) and I'Opinion (Errai), started publishing anti-colonial articles, advocating for the right to independence which was obtained in 1956.

Tunisia also was involved. Al Raid Al Tunisia was one of the few Arabic language papers that aimed to communicate with local populations and inform them about the hardships of the French presence even under protectorate status. In Algeria, however, 1954 was the date for the beginning of the revolution. In 1956, Free Radio Algeria under Mohamed Salah Soufi supervision was broadcast secretly from Moroccan territory in Nadhor. 
In the same year of 1954, there was the launch of the first Algerian nationalist newspaper, Al Moudjahid (The Fighter) which overtly and clearly supported the national liberation front in its struggle for independence from France. Another paper, Alger Republican - under Abdelhamid Benzine's editorship and with a handful of French journalists - which represented Algerian communist party, was directly supportive of Algerian revolution. It published articles that denounced French violation of human rights and the denial of Algerians' rights recovering their dignity and freedom. Further, some European and French journalists publicly expressed their outcry and wrote about the atrocities of the French soldiers in Algeria in their press, and that helped to evoke much public support from all parts of Europe.

\section{Political Leaders and Pen's Fighters}

Tunisia also was involved, thus Al Rai Al Tunisia was one of the few Arabic language papers that aimed to communicate with local populations and inform them about the hardships of the French presence even under protectorate status. The French occupation ended in Morocco in 1956 and then two years later in Tunisia. The two events had positive impact on the continuation of the Algerian revolution. Similtaneously, many african countries were positively effected; the winds of independence blew in other parts of the continent.

The mid 1950s period highlighted the key role played by political heroes like Moroccan King Mohamed V and Ghanaian leader Kwame Nkrumah who were sources of inspiration and examples to follow for many African leaders, journalists, writers and lawyers.

Psychiatrist and writer Frantz Fanon was one of the emblematic figures to support and defend the Algerian revolution against French occupation. It was clear, particularly in the case of Algeria, that the journalists considered themselves as "pen" and "voice" fighters for freedom and independence.

Many papers were published to defend those principles and values. Algérie Libre was the organ of the Algerian Movement for the Triumph of Democratic Liberties (MTLD), La République Algérienne was the voice of the Democratic Union for Algerian Truth and Al Bacair was published by the Algerian Muslim Ulama Association.

In the mid 1950s, Redha Malek, Mustapha Lachref, Chawki Mostefai, Mabrouk Belhocine and Mohamed El Mili, to cite just a few of them, were the first team of journalists to conceive and publish the first editions of Al Moudjahid in both languages (Arabic and French) which explicitly represented the Algerian National Liberal Front position. Those journalists felt morally, personally and ethically engaged in the revolution through their work. This earned them a wide international support and sympathy. Further, the Algerian cause gained worldwide media coverage and a better understanding of the real situation.

\section{From Militancy to Multiple Development Model}

It is recalled that after the independence in the 1960s each country in the region adopted its own political system. In Algeria, it was a one party system; in Tunisia it was more liberal on economics but very tight on political grounds and centered around the charisma of the Tunisian leader, Habib Bourguiba. Morocco remains a kingdom regime. 
Thus, analyzing the media in the post-independence era in North Africa region requires one to consider the social and cultural particularities of each country, as well as the political and economic system in which the media operate.

In addition to their traditional and natural African identity and relationship with sub-Saharan countries like Mali and Niger, Northern African countries share also cultural and social values with the Arab, Islamic world and Mediterranean sea area. Nevertheless, it is noticeable that after recovering their independence from France, the media in this region shifted from a militancy and independence advocacy role to national, social and economic development duties.

By decrees, laws and instructions in 1963 , the media was assigned to participate in the national development process and became the instrument for legitimatization of these new political systems, strengthening the fragile independence through the actions of education and mobilization of the population.

The euphoria and enthusiasm of the independence of the region enabled the press to be an intrinsic part of the political power if not power by itself. It was also committed to promoting, explaining, developing and defending social, cultural, economic and education activities and projects. Also, in the press literature, mobilisation, sensitisation, awareness, security and defence of the independence were the catch words to describe and define its role and duties during that period.

\section{Ruling Party and Elite}

However, the "developmental role" of the media did not last. It was undermined as it became ultimately the mouthpiece of the ruling party in regard to the National Liberation Front in Algeria, the ruling elite in Tunisia and the king of Morocco (4). In detail, the mobilising system in Algeria brought about a high degree of party and strict government control over the press in terms of editorial policies. The Tunisian loyalist system put the press at the service of the government in spite of being privately owned. In Morocco, although the press owed respect and submission to the king, it was still diverse and enjoyed some degree of editorial autonomy from government control and censorship. But the general trend was that under national sovereignty principles and for security reasons, the media had to abide by the strict rules of the country or face closure and censorship. The period which began in 1962 and ended 1988, was characterized years of self-censorship, "unanimity" and state ownership.

It was in fact a situation where, in Algeria for instance, the ruling party conceived, developed, implemented and supervised the information and communications policies through national committee structures and resolutions. The government was in charge of implementing them without any objection. In practice, the media was considered as the means and tool of the party to spread out ideologies to the population. As a consequence, the media became completely centralised and no private press was allowed.

The post independence years in Algeria saw the creation of many daily papers, the nationalisation of the colonial press and the strict control of privately owned ones. From 1964 to 1976,there was a sharp increase in circulation. This was partly due to the government developing infrastructures for the diffusion of the press, which illustrated the important role that the institution played in implementing the ruling party's ideologies and policies. 
However, the post-independence experience of the press in Morocco is slightly different. A great number of newspapers appeared and reflected diverse opinions and political affiliations. Apparently, Moroccan authorities did not interfere to stop diversity and plurality, although in practice local media operated by taking into account political considerations of the monarchy system (5).

In Tunisia, the print media was loyal to President Habib Bourguiba (1956-1987) and expressed support of the government in spite of being privately owned. As the analyst Professor Azzi has noted, the press was passive in its language, sensitive to the political environment and did not criticize national policy and personalities of the Tunisian government, although the Es Sabbah paper was the most critical paper in the country before 1971.

In 1987 when Tunisian president Ben Ali came to power, the press went through some relaxation, but since then the political environment has been gradually restricted. A lot of criticisms and challenges have arisen because of his tough grip on the political and media arenas. The ideology and practices of the one-party system still prevail in spite of what Tunisian media based abroad calls "cosmetic changes and démocratie de façade".

Bad records on human rights violations are denounced by local and international non-governmental organisations. Local journalists have told the international media that the political climate is under the strict control and dominance of the ruling party. Media freedom is often threatened and on many occasions journalists are arrested and jailed.

\section{Media as State Monopoly}

Electronic media was introduced into the region during French rule. Radio broadcasting began in the 1920s in Morocco and Algeria, whereas television appeared in 1950s. In Algeria, there were local radio stations based in the cities of Algiers, Oran, Souk Ahras and Tizi Ouzou under the French organ of radio and television (ORTF) and serving French communities. The first transmission of a television signal was in 1957.

In Morocco, broadcasting after the independence, when three radio stations were launched: Radio Tangier International, Radio Africa Maghreb in Tangier and Radio Dersa in Tetwan. Television was also launched then, and in 1966 in Tunisia.

After independence, governments in the region wholly owned and controlled the electronic media, except in Morocco where Radio Médi 1 station is a French and Saudi partnership. Thus, the Algerian Radio and Television company (RTA) emerged as sole electronic media enterprise in charge of advocating party/government policies, social integration and economic development. The same picture applied to Tunisian electronic media which appeared in 1966 and operated under undisputed public ownership and government control.

\section{The New Order of Information and Communication}

However, on an international level, North African countries were very active in calling for a new order of information and communication in the world. The idea was born during the Non-Aligned Movement summit in 1973 in Algeria. What should not be underestimated is the major work done by Tunisian scholar and diplomat Mus- 
tapha Masmoudi in 1970s and late 1980s at UNESCO on this issue. He should also be remembered for his academic contribution and publications on this sensitive issue, which still have effects on scholars and theorists in many developing countries including North African ones.

But in practice, those rightful claims were denied by United States, Great Britain and Singapore arguing that the package was too politicized and restricted the freedom of press and opinion. As a consequence, they withdrew from UNESCO and ceased financial contributions. Also, North/South dialogue as an alternative failed to meet expectations for justice and media freedom. Meanwhile, the United States developed new communications policies and strategies to wipe out hopes of setting up new order of information and communication in the world.

It was noticed that American media influence had overwhelmingly taken over the world and North African countries can only admit what Masmoudi has termed the "legacy of US media imperialism and hegemony" (8). Further East-West tensions affected the international political climate and media were also under their influences and pressures. In the late 1980s, and as a partial consequence of the US communications strategy, came the collapse of the communist bloc and the downfall of the Berlin Wall. It is evident that the American media network (radio, television, newspapers and news agencies) played a key role in "overthrowing socialist regimes" in the 1980s.

\section{Impact of Global Political Challenges}

In a global climate of political challenge and change, riots in Algeria in 1988 revealed the great anger of the population against one-party socialist policies. In 1989, the Algerian government adopted a new constitution that put an end to political monopoly and in 1990, a new bill of information was approved which protected freedom of expression and citizens' right of information and communication.

In Morocco, King Hassan II decided to allow the launch of a private radio station, Medi1, which enjoys a certain amount of freedom in its treatment of foreign affairs (9). Tunisia, however, under President Habib Bourguiba remained opposed to reforms in the electronic media.

Nevertheless, the 1990s sparked off political and economic reforms in the world and North African countries were obviously affected. As mentioned, each country tried to adopt its own policies to fit into the new political context. The private sector was encouraged and the formation of political parties and civil society promoted. The media is seen as part of the changes, and is solicited to implement the new package. It contributed to the introduction of democratic values and ideas. The proliferation of satellite dishes on the roofs of millions of buildings in Algeria, Tunisia, Morocco and Egypt illustrate the new spirit of press freedom and democracy. North African audiences have access to several hundred satellite TV channels as a reaction to present unsatisfactory national public media performance (10).

The process of globalisation and international communication networks are reconfiguring the world media, and North African media in the short term will be affected through their nature, content and approaches. In this transitional period, the public broadcasting service which is under pressure will have to adapt itself to survive in an environment of fiercer competition. The retention of state control 
over the media, and the public media's subordination of their functions to political power, should end and be replaced by more pluralism and independence. It is clear that the "wind of democratic changes" will ultimately blow away all old practices which do not fit into the new world political and media environment. However, arrogant attitudes in the US media about maintaining a world hegemony have contributed to skepticism, reluctance and lack of enthusiasm to more openness in the North African electronic media space.

Nevertheless, it is pitiful to notice that compared to Gulf states, the Arabic parts of the African continent, with the exception of Egypt, have done nothing substantial to develop a pluralist electronic media by approving private news TV channels. On the contrary, the region is still lagging behind in media development.

As an alternative, TV satellite channels like Al Jazeera, Al Arabiya, MBC, Dubai and Abu Dhabi have popular impact on North African audiences. Conspicuous is the lack of a news TV channel and this illustrates how politicians in North African countries are exerting pressure, monopoly and control on the news media. Private TV initiatives have not been encouraged, which again reflects a clear opposition of the present political system towards more openness and democracy.

Indeed, as the state media monopoly was maintained notably in Algeria, Algerian Berber TV broadcasts programs to the Berber community from France. The other private Algerian TV channel is Algérie Première, dedicated to youngsters, broadcast from Luxemburg. The Maghrebvision TV project for the region has never got off the ground. Observers noted that political differences and a leadership struggle obstructed its launch. Professor Mostafa Kraiem from Tunis University has clearly put it: "It can be observed that political decision makers in this region are still unaware of the necessity to introduce genuine audiovisual media pluralism." He asked: "Do they consider the situation is not ripe enough or are they not too confident to embrace a new adventure and admit private TV and radio stations in the public hands". The scholar further posed the question: "Are still socialist, nationalist and avant guardist ideas and movements too strong and well-rooted to oppose or refuse any democratic political and media move?".

\section{Media Status in 1990s}

The 1990 bill of information enabled the printed press to enjoy relative freedom and this is perceptible in the current press. Over 18 daily newspapers, most of them private, are published today. This bill was considered as a turning point in Algerian media history, doctrine and policy, and ignited the first "intellectual adventure" of Algerian media professionals.

Before that, the media were owned exclusively by the party state; it was dictated to and inspired by single-party ideology. Socialist and nationalist values were promoted and opponents denied access or simply silenced. Further, the media was the vehicle and vacuum of anti-imperialism and anti-colonialism ideas, whereas media professionals were assigned to militancy duties.

This situation did not last. The collapse of socialist regimes and the 1989 revolution in Eastern Europe had their effects on the future of the Algerian political system. One year before, riots and acts of violence took place in many cities, that sped up political and economic reforms and sparked off a shift to more openness and democracy. 
Considered as a front-runner in the region, Algeria was in the 1990s poised to initiate an innovative, pluralistic political and media system. Thus, the establishment of many independent authorities and structures such as the High Council for Information, Audiovisual council and council for culture, the removal of the information and communication ministry and the adoption of an independent legal status for radio and television, were the main ingredients to guarantee media pluralism, impartiality and independence.

In fact, in the case of High Council for Information, it was not independent as the president and some of his aides were nominated by the head of state whereas the rest of the members was elected by journalists representing the written press, news agency, radio and television. This procedure brought about tensions and disagreements because the president, in the last resort, had the right to exercise his veto. For the audiovisual council, it was a mixture of designated and elected members working as journalists, producers and technicians from television and cinema. The council of culture was composed of authors, writers and artists well known for their opposition to the unique political system. Although the experience was suspended following events related to terrorism, but these councils managed to produce some interesting and useful reports.

\section{PRESS UNDER TERRORISM}

For the first time in its post-independence history, precisely from 1989 to 1991 , Algerians enjoyed watching their local television programs and listening to radio. The new tone, style and frankness in news and current affairs programs gave more appetite to national and regional audiences in Tunisia and Morocco to stick to Algerian audiovisual programs.

However, the good news did not last long and, as one newspaper put it, "the break is over". Authorities decided to freeze the activities of independent bodies by re-establishing the ministry of information and communication in 1995. The bad news increased when Algeria embarked on long term cycle of disorder, anarchy, violence and terrorism after the annulment of the election results of December 26 1991. The press was severely affected: over 65 journalists were killed, hundreds were forced into exile and those who remained kept a low profile to secure their lives. The urgent goals of the authorities were to reestablish peace, stability and security in Algeria.

\section{New Media Era}

The year 2000 sees the end of terrorism at large scale and a gradual resumption of normal political life with the adoption of a new bill of organic information law enhanced by another bill on audiovisual activities that waive all restrictions and put an end to the public audiovisual monopoly. So, if the 1990's bill of information paved the way for more pluralism and diversity in the printing media, the 2012 organic law of information formally adopted the end of audio visual public authority.

In January 2014, a new Audiovisual Activities Bill was approved to enable private companies and individuals to invest in the field. Since then, Algerian audiovisual media landscape have been garnished with over 44 private TV stations. In so far, public television still has a dominant position (human and material resources) 
and new private 'off shore' television channels are broadcasting without any legal framework; only 5 of them are formally authorised.

For the radio stations segment, there are only public ones due to the scarcity of frequencies spectrum. All public radio stations are still on analogue system and only available on frequency modulation.

\section{CONCLUSION}

Today Algerians enjoy watching variety of TV channels, they are over 40 channels offering series of programs with different views and opinions on different issues but without any strict regulation. However, to put an end to such a 'mess', the authorities have set up in January 2014 an authority of regulation in the audio visual field. This new body will certainly bring about new rules to be observed by all actors and operators for more professionalism and independence. Ultimately, it will guarantee the rise of professional TV channels and pave the way to establish new audio visual media landscape based on principles of pluralism and respect of ethics.

\section{Bibliographic References}

Azzi.A, Al Sahafa Al Arabia, Kiraa Taqyimia fi, Thalouth William Rugh (1989). El Fijr ElArabi. In Merrill, J.C. Global Journalism. 196-201.

Bedjaoui.A. (2006). 'L'Image entre la télévision et le cinéma: Enjeux d Avenir'. In Conférence à ISIC Université de Rabat. Morocco.

Bensalah. M. (2006). 'Les Mutations du Paysage Audiovisuel International : L'Espace Médiatique Maghrébin' Actes du Colloque Université de Manouba Tunis et Fondation Konrad Adenauer.

Brahimi, B. (1990). Le Pouvoir, la Presse et les Intellectuels Editions SNED Alger

Chalabi. E.H. (1992). La Constitution du 23 Février 1989 Entre Dictature et Démocratie. NAOD Review Algiers.

Ihaddaden, Z (1992). 'Histoire de la Presse Indigène en Algérie Enal Alger / The Post Colonial Policy on Algerian Broadcasting'. In Rigins, S, H. Ethnic Minority Media. Newburry Park: Sage. Institut Panos. (1996) (éd.), Ne tirez pas sur les médias, Paris, L'Harmattan.

Institut Panos Paris (ed.) (1999). Legislations et pluralisme radiophonique en Afrique de I'Quest. Paris, Harmattan.

Kraiem, M. 'La Télévision dans les pays arabes : Les régimes arabes et les moyens moder-

nes de communication'. In Conférence Université de Tunis I, from http://www.kalimatunisie.com

Masmoudi, M. (1998). The New Communication Order at Cross Roads. Mbay'o, R.T., Onwumechili, C. and Nwanko, R.N. (2000). (eds). Press and Politics in Africa. Lewiston: The Edwin Mellon Press.

Mostefaoui, B. (1986). Usage des Medias en Question. Algiers, OPU.

Schramm, W. (1964). Mass media and national development:The role of information in the developing countries. Paris / California: Unesco / Stanford University Press.

Servaes, J. (1991). Towards a new perspective for communication and development. In Casmir, F. (eds). Communication in development. Norwood, NJ: Ablex Publishing. 
Shah, H. (1996). Modernisation, Marginalisation, and Emancipation: Toward a Normative Model of Journalism and National Development. Communication Theory. 6(2): 143-166. Wisdom J. (2006) "The Politics of Media Accountability in Africa: An Examination of Mechanisms and Institutions." International Communication Gazette,

Vol. 68, No. 3, 229-248.

Wedell, G. (ed). (1986). Making broadcasting useful: the African experience: the development of radio and television in Africa in the 1980s. (Kangwana, $\mathrm{J}$ and Lawler,

L asst ed). Manchester: Manchester University Press.

Welch, C.E. (Ed) (1970) Soldier and State in Africa. A Comparative Analysis of Military Intervention and Political Change. Evanston, Northwestern University Press.

Zaghlami, L. (1994). Mass Media in the Middle East. USA, Greenwood Press.

Zaghlami, L. (1999). Images of the US around the World, An Algerian Perspective. New York, New York University Press.

Zaghlami, L. (2006). 'News at Algerian TV'. The Channel Magazine, UK.

Zaghlami, L. (2007, April). 'Media Studies and Practices'. In Journal of African Media Studies. 1(1)

Zaghlami, L (2010), in Citizen Journalism and Democracy in Africa, Rhodes University South Africa July 2010

Zaghlami, Laeed (2015), 'Enough' Algeria's New Broadcast Landscape' in The Channel UK issue 1,2015 page 45 